Original Research

\title{
Effects of Grazing Exclusion on Soil Properties in Maqin Alpine Meadow, Tibetan Plateau, China
}

\author{
Hongqin Li ${ }^{1,2}$, Fawei Zhang1, , Shaojuan $\mathrm{Mao}^{4}$, Jingbin $\mathrm{Zhu}^{1,3}$, \\ Yongsheng Yang ${ }^{1,2}$, Huidan $\mathrm{He}^{1,3}$, Yingnian $\mathrm{Li}^{1,2 *}$ \\ ${ }^{1}$ Northwest Institute of Plateau Biology, Chinese Academy of Sciences, Xining, China \\ ${ }^{2}$ Key Laboratory of Adaptation and Evolution of Plateau Biota, Chinese Academy of Sciences, Xining, China \\ ${ }^{3}$ University of Chinese Academy of Sciences, Beijing, China \\ ${ }^{4}$ Qinghai University, Xining, China
}

Received:29 September 2015

Accepted: 7 March 2016

\begin{abstract}
Grazing exclusion with fencing has been widely implemented to rehabilitate degraded grasslands in China. However, the response of grassland ecosystems has remained controversial among sites and vegetation types. In this study, characteristics of vegetation and soil properties under degradation gradients (light and middle) and grazing exclusion were examined in the Maqin alpine meadow in August 2013. The results showed that grazing exclusion resulted in a significant recovery in vegetation with higher above- and below-ground biomasses, which reached $459.29 \mathrm{~g} \cdot \mathrm{m}^{-2}$ and $5,657.93 \mathrm{~g} \cdot \mathrm{m}^{-2}$ in comparison with $132.53 \mathrm{~g} \cdot \mathrm{m}^{-2}$ and $1,494.37 \mathrm{~g} \cdot \mathrm{m}^{-2}$ in middle degraded plots, respectively. Soil bulk density in grazing exclusion decreased especially obviously in the $0-10 \mathrm{~cm}$ layer. Soil capillary and saturated water in grazing exclusion increased to $1,075.2 \mathrm{~g} \cdot \mathrm{kg}^{-1}$ and $1,072.4 \mathrm{~g} \cdot \mathrm{kg}^{-1}$, respectively, in the $0-10 \mathrm{~cm}$ layer. They also increased a little in the 10-20 cm layer. Grazing exclusion had significant positive effects on soil organic carbon and total nitrogen content, especially in the $0-10 \mathrm{~cm}$ layer. The results above indicated that grazing exclusion was an effective restoration approach to rehabilitate degraded alpine meadow in Maqin.
\end{abstract}

Keywords: grazing exclusion, soil properties, degraded grassland, alpine meadow, rehabilitation

\section{Introduction}

Grassland, as an important part of the terrestrial ecosystem, plays an essential role in water conservation and forage productivity in the Qinghai-Tibetan Plateau [1, 2]. However, many extensive ecological problems such

*e-mail: ynli@nwipb.cas.cn

as grassland degradation have been caused recently by human activity and global warming in Qinghai-Tibetan Plateau [3]. There were many poisonous and ruderal weeds that were inedible for livestock in the warm season and little vegetation coverage in the cold season in the severely degraded grassland, leading to rodent infestation and soil degradation.

Soil condition is the cornerstone of grassland health and soil degradation refers to the degradation of soil 
properties, including physical and chemical properties, and is the key problem of grassland degradation. Soil degradation obviously lags behind vegetation degradation and is not apparent. However, once the soil degrades, its recovery period is long and difficult [4].

The severely degraded grassland not only greatly reduces foraging productivity but also leads to ecological problems. Degraded grassland is widespread and has recently been spreading across the Qinghai-Tibetan Plateau. Therefore, various measures have been implemented with the aim of rehabilitating degraded grassland in which grazing exclusion is widely employed as an effective tool.

In recent years, intensive studies have been conducted concerning the effects of grazing exclusion or degradation on grassland - especially on vegetation [5], soil nutrients [6], and soil seed banks [7]. However, studies on the effectiveness of grazing exclusion have had many inconsistent results. Several researchers $[8,9]$ found that grazing exclusion could strongly increase soil fertility and carbon storage. Others [10] reported that soil carbon storage decreased at non-grazed sites compared with adjacent grazed sites. The different results between studies might be related to location, grassland type, and exclusion time. Nevertheless, relevant studies in the alpine region were inadequately conducted because of the harsh climate.

Maqin County (hereafter Maqin), located in southeast Qinghai Province, is the national "three river sources" ecological reservoir. Alpine meadow occupies 1.31 million $\mathrm{hm}^{2}$, covering $91 \%$ of Maqin. Alpine meadow encountered a similar degradation problem as grassland in other areas. Grazing exclusion was generally adopted to recover the degraded meadow in this region while the response of soil and plants was not fully understood. So quantifying the effects of grazing exclusion is helpful for better understanding these restorations mechanisms and for developing appropriate management and conservation techniques for degraded grassland.

\section{Materials and Methods}

\section{Study Area}

This study was conducted in Maqin grassland of Qinghai Province, China, which is located in the eastern part of Qinghai-Tibetan Plateau with an average altitude of $3,700 \mathrm{~m}$. The mean annual precipitation is between
423-565 $\mathrm{mm}$ and annual air temperature is between -3.8 to $3.5^{\circ} \mathrm{C}$, respectively. The vegetation surrounding the study site is classified as Kobresia meadow. Root concentrated depth is about $0-30 \mathrm{~cm}$.

\section{Field Sample and Laboratory Analysis}

We established three experiment plots with similar soil types and plant species within Maqin grassland, including medium degradation (MD), light degradation (LD), and grazing exclusion (GE, which has been fenced since 2005; Table 1). The field survey was carried out in August 2013, which is a typical period of peak aboveground biomass. In each plot, three sampling quadrats $(50 \mathrm{~cm} \times 50 \mathrm{~cm})$ were established randomly. Aboveground biomass in these quadrats was determined by clipping the plants above the ground and drying for constant weight. Then at the center of each quadrat, belowground biomass of $0-10 \mathrm{~cm}, 10-20 \mathrm{~cm}$, and 20-30 $\mathrm{cm}$ depth were collected using a soil sampler of $8 \mathrm{~cm}$ diameter. Samples were washed to remove the soil and stone. Aboveground and belowground biomasses were dried at $65^{\circ} \mathrm{C}$ for about $24 \mathrm{~h}$ and $48 \mathrm{~h}$ to a constant weight, respectively. Soil samples were collected using a soil sampler (diameter $3 \mathrm{~cm}$ ) from three layers of 0-10 cm, 10$20 \mathrm{~cm}$, and $20-30 \mathrm{~cm}$. Samples were air-dried and cleared of roots for analyzing the soil organic carbon and total nitrogen contents, which were determined by oil bath$\mathrm{K}_{2} \mathrm{CrO}_{7}$ titration method and $\mathrm{K}_{2} \mathrm{CrO}_{7}+\mathrm{H}_{2} \mathrm{SO}_{4}$ digestion, respectively. They were measured by the Analytical Testing Center at the Northwest Institute of Plateau Biology, Chinese Academy of Sciences.

Soil bulk density and water-holding capacity were measured in a series of experiments with a soil wreath knife. Natural soil along with soil wreath knife is weighed $\left(\mathrm{m}_{\mathrm{s} 1}, \mathrm{~g}\right)$ after $12 \mathrm{~h}$ of soaking to calculate the saturated water content $\left(\mathrm{C}_{\max }, \mathrm{g} \cdot \mathrm{cm}^{-3}\right)$. Put on the dry sand for $2 \mathrm{~h}$ when non-pore water is drained out completely, and weighed $\left(\mathrm{m}_{\mathrm{s} 2}, \mathrm{~g}\right)$ to calculate capillary water content

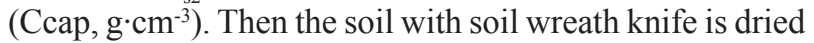
to constant weight $\left(\mathrm{m}_{\mathrm{s} 3}, \mathrm{~g}\right)$. Finally, the soil wreath knife is weighed $\left(\mathrm{m}_{\mathrm{s} 0}, \mathrm{~g}\right)$. The details of the method can be found in "Research Method of Forest Soil" [11]. The equations of soil bulk density $(D)$ and water-holding capacity are as follows:

$$
D=\frac{m_{s 3}-m_{s 0}}{V} \quad C_{\max }=\frac{m_{s 1}-m_{s 3}}{m_{s 3}-m_{s 0}} \quad C_{c a p}=\frac{m_{s 2}-m_{s 3}}{m_{s 3}-m_{s 0}}
$$

Table 1. Vegetation characteristics of grazing exclusion and degraded grassland.

\begin{tabular}{|c|c|c|l|c|c|}
\hline Treatment & Dominant species & $\begin{array}{c}\text { Coverage } \\
(\%)\end{array}$ & Soil type & $\begin{array}{c}\text { Aboveground } \\
\text { biomass g.m }{ }^{-2}\end{array}$ & $\begin{array}{c}\text { Belowground } \\
\text { biomass } \mathrm{g} \cdot \mathrm{m}^{-2}\end{array}$ \\
\hline $\mathrm{GE}$ & Stipa, Kobresia, Poa annua & 100 & Subalpine meadow soil & 459.29 & $5,657.93$ \\
\hline LD & $\begin{array}{c}\text { Stipa, Kobresia, Ajania } \\
\text { tenuifolia }\end{array}$ & 98 & Subalpine meadow soil & 160.97 & $2,317.18$ \\
\hline MD & Stipa, Ligularia virgaurea & 65 & Subalpine meadow soil & 132.53 & $1,494.37$ \\
\hline
\end{tabular}




\section{Results}

\section{Vegetation Response}

Soil types of all the three sites were subalpine meadow soil (Table 1). Stipa and Kobresia were typical plants in this area and were the dominant species in GE and LD (Table 1). Coverage by poisonous weeds increased greatly and Stipa decreased greatly in MD. Plant coverage was $100 \%$ and $65 \%$ in $\mathrm{GE}$ and $\mathrm{MD}$, and decreasing with degradation gradients. Aboveground biomass in GE reached 459.29 $\mathrm{g} \cdot \mathrm{m}^{-2}$, which was much higher than that in the degraded plots. It was only $132.53 \mathrm{~g} \cdot \mathrm{m}^{-2}$ in MD and was just one third of GE. Belowground biomass showed the same trend with aboveground biomass among these plots (Table 1).

\section{Bulk Density and Water-Holding Capacity}

Analysis of variance showed significant differences in bulk density, capillary water, and saturated water between GE and degraded plots, and these differences depended on soil depth (Table 2). Bulk density ranged from 0.49 to $1.41 \mathrm{~g} \cdot \mathrm{cm}^{-3}$ and increased with increasing soil depth. Grazing exclusion could significantly decrease topsoil $(0-10 \mathrm{~cm})$ bulk density by $50.50 \%$ and $54.21 \%$ compared with that in LD and MD. Although soil bulk density in GE was also the lowest at $10-20 \mathrm{~cm}$, it was not significantly altered in response to grassland degradation. Similarly, there was little significant difference of the soil bulk density in 20-30 cm between GE and degraded plots. In $10-20 \mathrm{~cm}$, bulk density in GE was just higher than that in MD.

Soil water-holding capacity is the amount of water that a given soil can hold against the force of gravity. Soil capillary water and saturated water were both higher in GE compared with degraded grassland (Table 2). Capillary water varied from 288.2 to $1,509 \mathrm{~g} \cdot \mathrm{kg}^{-1}$ and negatively correlated with bulk density. It was higher in GE and was highest at $0-10 \mathrm{~cm}$ depth. It decreased along degradation gradients and soil depth. Saturated water positively related to capillary water. Meanwhile, capillary water was very close to saturated water, suggesting that capillary porosity accounted for most of the soil porosity and was an appropriate indicator for soil water-holding capacity.

\section{Soil Organic Carbon and Total Nitrogen Content}

Soil organic carbon content was higher in GE than that in the degraded plots of all three soil layers (Fig. 1). Soil organic carbon content of $0-10 \mathrm{~cm}$ reached $80.87 \mathrm{~g} \cdot \mathrm{kg}^{-1}$ in GE and $11.85 \mathrm{~g} \cdot \mathrm{kg}^{-1}$ in LD. The difference between GE and degraded plots decreased in deeper soil. Surprisingly, soil organic carbon content of $0-10 \mathrm{~cm}$ and $10-20 \mathrm{~cm}$ in $\mathrm{MD}$ was higher than that in $\mathrm{LD}$.

Total soil nitrogen content decreased along degradation gradients and soil depth (Fig. 2) and was higher in GE than in MD and LD. The significant difference occurred only in the $0-10 \mathrm{~cm}$ soil layer. In general, grazing exclusion had significant positive effects on total nitrogen content, ranging from $5.44 \mathrm{~g}^{\mathrm{kg}}{ }^{-1}$ in $\mathrm{MD}$ to $12.68 \mathrm{~g} \cdot \mathrm{kg}^{-1}$ in $\mathrm{GE}$, and decreased with degradation gradients (Fig. 2).

\section{Discussion}

Overgrazing of livestock can alter plant communities and cause soil erosion and loss of biodiversity, and this is the main factor that has led to grassland degradation across the Qinghai-Tibetan Plateau. Changes of community composition and structure were the symbols of grassland degradation. These were mainly reported in biomass decline, ruderal increase, and a reduction in quality forage [12]. Grazing exclusion was generally expected to improve plant cover, plant biomass, and species biodiversity $[13,14]$, and then promote the stability and sustainable development of the grassland.

Table 2. Soil bulk density and water-holding capacity of grazing exclusion and degraded grassland.

\begin{tabular}{|c|c|c|c|c|}
\hline $\begin{array}{c}\text { Soil layer } \\
(\mathrm{cm})\end{array}$ & Treatment & $\begin{array}{c}\text { Bulk density } \\
\mathrm{g} \cdot \mathrm{cm}^{-3}\end{array}$ & $\begin{array}{c}\text { Capillary water } \\
\mathrm{g} \cdot \mathrm{kg}^{-1}\end{array}$ & $\begin{array}{c}\text { Saturated water } \\
\mathrm{g} \cdot \mathrm{kg}^{-1}\end{array}$ \\
\hline \multirow{3}{*}{$0-10$} & GE & $0.49 \pm 0.01 \mathrm{a}$ & $1,509.0 \pm 51.08 \mathrm{a}$ & $1,528.00 \pm 51.71 \mathrm{a}$ \\
\cline { 2 - 5 } & LD & $0.99 \pm 0.03 \mathrm{~b}$ & $591.60 \pm 27.93 \mathrm{~b}$ & $601.70 \pm 21.91 \mathrm{~b}$ \\
\cline { 2 - 5 } & MD & $1.19 \pm 0.01 \mathrm{c}$ & $433.80 \pm 8.26 \mathrm{c}$ & $455.60 \pm 19.17 \mathrm{c}$ \\
\hline \multirow{3}{*}{$10-20$} & GE & $1.03 \pm 0.02 \mathrm{a}$ & $544.90 \pm 22.43 \mathrm{a}$ & $553.60 \pm 23.33 \mathrm{a}$ \\
\cline { 2 - 5 } & LD & $1.16 \pm 0.04 \mathrm{ab}$ & $448.50 \pm 19.78 \mathrm{ab}$ & $460.20 \pm 18.50 \mathrm{ab}$ \\
\hline \multirow{3}{*}{$20-30$} & MD & $1.26 \pm 0.10 \mathrm{~b}$ & $395.40 \pm 49.41 \mathrm{~b}$ & $405.70 \pm 55.38 \mathrm{~b}$ \\
\cline { 2 - 5 } & GE & $1.41 \pm 0.03 \mathrm{a}$ & $309.80 \pm 1.32 \mathrm{a}$ & $316.40 \pm 13.96 \mathrm{a}$ \\
\cline { 2 - 5 } & LD & $1.27 \pm 0.09 \mathrm{a}$ & $381.40 \pm 5.61 \mathrm{a}$ & $393.00 \pm 57.06 \mathrm{a}$ \\
\hline
\end{tabular}

Notes: Different letters mean significant differences $(P<0.05)$ between the treatments. Values following “ \pm ” represent standard error. 


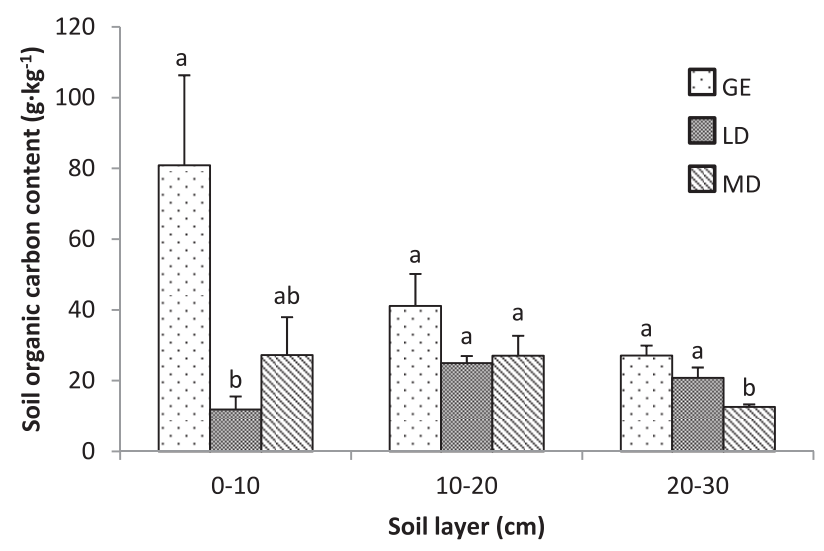

Fig. 1. Soil organic carbon content in grazing exclusion and degraded grassland.

Notes: Different letters mean significant differences $(P<0.05)$ between the treatments. Error bars represent standard error.

Livestock grazing, which is the most common form of land use, may also cause spatial variations of vegetation and soil properties over the Qinghai-Tibetan Plateau [15]. The results in this study showed that grazing exclusion in Maqin alpine meadow could obviously increase above-

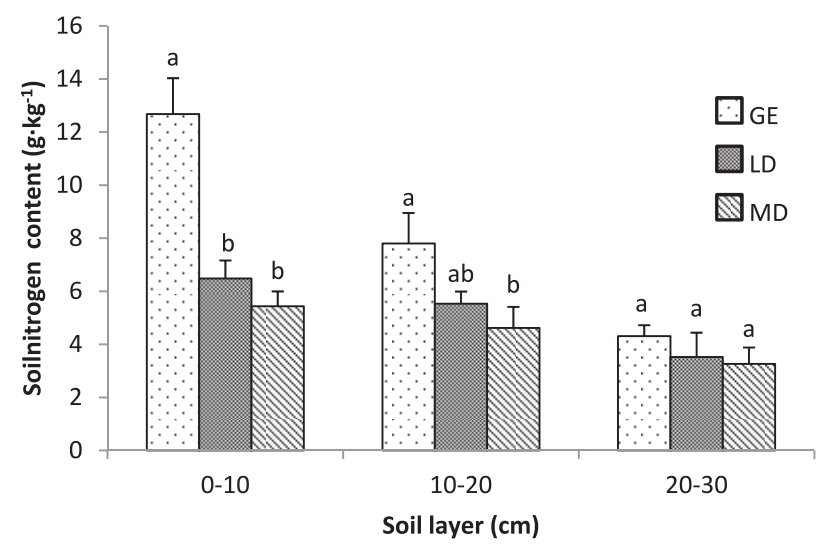

Fig. 2. Soil nitrogen content in grazing exclusion and degraded grassland.

Notes: Different letters mean significant differences $(P<0.05)$ between the treatments. Error bars represent standard error.

and belowground biomass and coverage, which was coincident with other studies $[16,17]$. As we know, longterm grazing accelerated leaf and shoot loss by domestic animal browsing and trampling, which should affect community composition and result in lower above- and belowground biomass and palatable species coverage. After grazing exclusion and the removal of animal ingestion, biomass and coverage accumulated - especially edible forage, for example Stipa and Kobresia. Then they turned out to be the dominant species in the grazing exclusion for years.

The increased ground cover following exclusion of livestock effectively protected fine soil particles from loss by wind erosion. The elimination of soil trampling by livestock, as well as the high organic matter content and the presence of extensive shallow root systems, contributed to a significant decrease in bulk density of the exclusion areas. But this appeared in the top soil layer, which is consistent with the results of other researchers who found that during restoration of degraded land regions, soil improvement occurred primarily at the surface [18].

The results showed that soil carbon and nitrogen content increased significantly in GE, and this is in agreement with other studies. The improvement of soil carbon and nitrogen to some extent was due to an increase in plant organic matter inputs. Grazing exclusion induced a large amount of litter. Improvement of soil nutrient conditions in grassland can promote the growth of plant species and biomass accumulation, especially for palatable grasses that have grater competitive abilities than unpalatable grasses. Therefore, a grazing exclusion could trigger a positive loop. Higher soil nutrients are probably caused by the larger community coverage. Many reporters have found that the plant coverage had a significant positive effect on soil qualities in grassland $[19,20]$. Degraded grassland produces much less and poorer forage production. Consequently, it causes serious problems with livestock production and environmental protection.

Soil nitrogen content in MD was lower than in LD. This was agreed upon with many studies, but the soil carbon content of $0-20 \mathrm{~cm}$ in MD was higher than in LD. One explanation was that inedible plants had higher root/shoot ratios, which could increase the distribution of carbon to soil in MD [21]. Another explanation was that soil changes tended to have non-synchronization with the evolution of vegetation in the degeneration process. Soil changes lagged behind the vegetation transition [22].

Soil water capacity is fundamental to grassland ecosystem functions owing to its driving force to plant productivity and its regulations of biogeochemical process in soils [23]. Land use patterns could have a substantial influence on soil water-holding capacity [24]. In this study, soil in GE had the maximum water-holding capacity with higher capillary and saturated water because growing grass root might be important for increasing water-holding capacity. Besides, biochar addition could increase waterholding capacity of the soil [25].

\section{Conclusion}

Above- and belowground biomass in grazing exclusion were higher than in the degraded grassland. Vegetation coverage and edible forage also were raised in the grazing exclusion. Grazing exclusion could significantly decrease soil bulk density, especially in the upper layer. Soil capillary water and saturated water were both higher in grazing exclusion compared with grazing grassland in the $0-30 \mathrm{~cm}$ depth. Soil organic carbon and nitrogen content were much higher in the grazing exclusion, so we concluded that grazing exclusion was an effective restoration approach to control grassland degradation in Maqin. 


\section{Acknowledgements}

This work was supported by the Natural Science Foundation of Qinghai Province (No. 2014-ZJ-901), the National Natural Science Foundation of China (Nos. 31300385, 31270523), the Strategic Priority Research Program of the Chinese Academy of Sciences (No. XDB03030502), and the International Cooperation Research Program of Qinghai Province (No. 2015-HZ804).

\section{References}

1. HAO X. A green fervor sweeps the Qinghai-Tibetan Plateau. Science. 321, 633, 2008.

2. FENG R., LONG R., SHANG Z., MA Y., DONG S., WANG Y. Establishment of Elymus natans improves soil quality of a heavily degraded alpine meadow in Qinghai-Tibetan Plateau, China. Plant and Soil. 327 (1-2), 403, 2010.

3. RUI Y., WANG S., XU Z., WANG Y., CHEN C., ZHOU X., KANG X., LU S., HU Y., LIN Q., LUO C. Warming and grazing affect soil labile carbon and nitrogen pools differently in an alpine meadow of the Qinghai - Tibet Plateau in China. Journal of Soils and Sediments. 11 (6), 903, 2011.

4. REEDER J.D., SCHUMAN G.E. Influence of livestock grazing on $\mathrm{C}$ sequestration in semi-arid mixed-grass and short-grass rangelands. Environmental Pollution. 116 (3), 457, 2002.

5. REN G., SHANG Z., LONG R., HOU Y., DENG B. The relationship of vegetation and soil differentiation during the formation of black-soil-type degraded meadows in the headwater of the Qinghai-Tibetan Plateau, China. Environmental Earth Sciences. 69 (1), 235, 2013.

6. WU X., LI Z., FU B., LU F., WANG D., LIU H., LIU G. Effects of grazing exclusion on soil carbon and nitrogen storage in semi-arid grassland in Inner Mongolia, China. Chinese Geographical Science. 24 (4), 479, 2014.

7. SHANG Z., DENG B., DING L., REN G., XIN G., LIU Z., WANG Y., LONG R. The effects of three years of fencing enclosure on soil seed banks and the relationship with aboveground vegetation of degraded alpine grasslands of the Tibetan plateau. Plant and Soil. 364 (1-2), 229, 2013.

8. NIU D., HALL S.J., FU H., KANG J., QIN Y., ELSER J.J. Grazing exclusion alters ecosystem carbon pools in Alxa desert steppe. New Zealand Journal of Agricultural Research. 54 (3), 127-142, 2011.

9. LI Y., ZHOU X., BRANDLE J. R., ZHANG T., CHEN Y., HAN J. Temporal progress in improving carbon and nitrogen storage by grazing exclosure practice in a degraded land area of China's Horqin Sandy Grassland. Agriculture Ecosystems \& Environment. 159, 55, 2012.

10. NOSETTO M.D., JOBBAGY E.G., PARUELO J.M. Carbon sequestration in semi-arid rangelands: Comparison of Pinus ponderosa plantations and grazing exclusion in NW Patagonia. Journal of Arid Environments. 67 (1), 142, 2006.

11. ZHANG W., XV B. The method of Long-term Research on Forest Soil. Beijing: Chinese Forestry Press. 30-36, 1986.
12. LIU Y., FAN J., LI Y., ZHANG L. Plant community productivity and diversity on alpine meadow steppe in the Three River Headwater Region, Qinghai Province under different denudation levels. Acta Prataculturae Sinica. 23 (03), 1, 2014.

13. LI Y., DONG S., LI X., WEN L. Effect of grassland enclosure on vegetation composition and production in headwater of yellow river. Acta Agrestia Sinica, 20 (2), 275, 2012.

14. VERDOODT A., MUREITHI S. M., YE L., VAN RANST E. Chronosequence analysis of two enclosure management strategies in degraded rangeland of semi-arid Kenya. Agriculture Ecosystems \& Environment. 129 (1-3), 332, 2009.

15. DONG Q., ZHAO X., WU G., SHI J., REN G. A review of formation mechanism and restoration measures of "black-soil-type" degraded grassland in the Qinghai-Tibetan Plateau. Environmental Earth Sciences. 70 (5), 2359, 2013.

16. CHENG J., WU G.L., ZHAO L.P., LI Y., LI W., CHENG J.M. Cumulative effects of 20-year exclusion of livestock grazing on above- and belowground biomass of typical steppe communities in arid areas of the Loess Plateau, China. Plant Soil and Environment. 57 (1), 40, 2011.

17. JING Z., CHENG J., SU J., BAI Y., JIN J. Changes in plant community composition and soil properties under 3-decade grazing exclusion in semiarid grassland. Ecological Engineering. 64, 171, 2014.

18. CHEN Y., LI Y., ZHAO X., AWADA T., SHANG W., HAN J. Effects of grazing exclusion on soil properties and on ecosystem carbon and nitrogen storage in a sandy rangeland of inner mongolia, northern china. Environmental Management. 50 (4), 622, 2012.

19. MARZAIOLI R., D'ASCOLI R., DE PASCALE R.A., RUTIGLIANO F.A. Soil quality in a Mediterranean area of Southern Italy as related to different land use types. Applied Soil Ecology. 44 (3), 205, 2010.

20. ZHANG C., XUE S., LIU G., SONG Z. A comparison of soil qualities of different revegetation types in the Loess Plateau, China. Plant and Soil. 347 (1-2SI), 163, 2011.

21. DERNER J.D., BRISKE D.D., BOUTTON T.W. Does grazing mediate soil carbon and nitrogen accumulation beneath $\mathrm{C}_{4}$, perennial grasses along an environmental gradient?. Plant and Soil. 191, 147, 1997.

22. DING Y., NIU J., YANG C. Plant community succession of degradation and desertification in sandy grassland. Chinese Journal of Ecology. 25 (09), 1044, 2006.

23. STAVI I., UNGAR E.D., LAVEE H., SARAH P. Grazinginduced spatial variability of soil bulk density and content of moisture, organic carbon and calcium carbonate in a semiarid rangeland. Catena. 75 (3), 288, 2008.

24. LIU Y., GAO M., WU W., TANVEER S.K., WEN X., LIAO Y. The effects of conservation tillage practices on the soil water-holding capacity of a non-irrigated apple orchard in the Loess Plateau, China. Soil \& Tillage Research. 130, 7, 2013.

25. BASSO A.S., MIGUEZ F.E., LAIRD D.A., HORTON R., WESTGATE M. Assessing potential of biochar for increasing water-holding capacity of sandy soils. GCB Bioenergy. 5 (2), 132, 2013. 